\title{
IMPLEMENTASI PEMBELAJARAN BERBASIS 4C OLEH GURU BAHASA JEPANG DI SMA NEGERI 2 SEMARAPURA
}

\author{
N, L, P, Suastini ${ }^{1}$. D, M, S, Mardani ${ }^{2}$. dan G, S, Hermawan ${ }^{3}$ \\ ${ }^{123}$ Jurusan Pendidikan Bahasa Jepang, Universitas Pendidikan Ganesha, Singaraja \\ e-mail: luh.putu.suastini@undiksha.ac.id, desak.mardani@undiksha.ac.id, satya.hermawan@undiksha.ac.id,
}

Abstrak

Penelitian ini bertujuan untuk mendeskripsikan implementasi pembelajaran berbasis $4 \mathrm{C}$ dan kendala-kendala yang dihadapi guru dalam mengimplementasikan pembelajaran berbasis $4 \mathrm{C}$ di SMA Negeri 2 Semarapura. Penelitian ini menggunakan metode deskriptif kualitatif. Subjek penelitian ini adalah guru bahasa Jepang kelas X di SMA Negeri 2 Semarapura. Data dikumpulkan melalui metode observasi partisipasi pasif dan metode wawancara semi terstruktur yang berkaitan dengan implementasi pembelajaran berbasis 4C. Hasil penelitian menunjukan bahwa implementasi pembelajaran berbasis $4 \mathrm{C}$ sudah sesuai dengan langkah-langkah (critical thinking and problem solving, creativity and innovations, communication, and collaboration). Kenda

Kata kunci: Implementasi, pembelajaran berbasis 4C, critical thinking and problem solving

\section{要旨}

本研究の目的は、4Cに基づく学習及び教師が直面する障害を説明する。このデータ を定性的記述法により分析した。調査協力者はセマラプラ第二国立高校の一年生の 教師である。調査方法は、観察及びインタビューである。その結果は、4Cに基づく 学習実施は4Cに基づく学習に従って実装されたことを示した。その4Cは批判的思考 と問題解決、コミュニケーション、コラボレーション、創造性と革新である。教師 が直面した4Cに基づく学習実施の障害は批判的思考と問題解決の活動では少数の学 習者はあまり活発しなかった。教師がとる解決策は、材料を言うだけでなく、生徒 の好奇心を刺激するのに積極的な役割を果たすことでもある。

\section{キーワード : 実施、4Cに基づく学習、批判的思考と問題解決}

\section{Pendahuluan}

Sesuai dengan undang-undang RI No. 20 Tahun 2003 tentang sistem Pendidikan Nasional berdasarkan Pancasila dan Undang-undang dasar 1945, Fungsi dan Tujuan Pendidikan Nasional dituangkan dalam UU Nomor 20 tahun 2003 tentang Sisdiknas pasal 3 yang berbunyi: "Pendidikan nasional berfungsi mengembangkan kemampuan dan membentuk watak serta peradaban bangsa yang bermartabat dalam rangka mencerdaskan kehidupan bangsa, bertujuan untuk mengembangkan potensi peserta didik agar menjadi manusia yang beriman dan bertakwa kepada Tuhan Yang Maha Esa, berakhlak mulia, sehat, berilmu, cakap, kreatif, mandiri dan menjadi warga Negara yang demokratis serta bertanggung jawab". Memperhatikan Dasar, Fungsi, dan Tujuan Pendidikan Nasional di atas, pada dasarnya pendidikan di Indonesia merupakan pendidikan berkarakter yang unik sesuai dengan budaya Indonesia, maka dari itu sangat sejalan dengan tuntutan kecakapan Abad 21 dengan segala tantangannya. Untuk mencapai fungsi dan tujuan pendidikan nasional, pemerintah Indonesia melakukan berbagai upaya salah satunya yaitu perubahan kurikulum.

Kurikulum sangat diperlukan dalam dunia pendidikan karena kurikulum merupakan landasan pokok dalam pendidikan. Selain itu, kurikulum dapat menunjang pencapaian tujuan pendidikan. Kurikulum merupakan seperangkat rencana dan pengaturan mengenai tujuan, isi dan bahan pelajaran serta cara yang akan digunakan sebagai pedoman penyelenggaraan kegiatan pembelajaran untuk mencapai tujuan pendidikan tertentu.

Perubahan kurikulum 2013 yang sesuai dengan Permendikbud No 22 Tahun 2016 tentang Standar Proses Pendidikan Dasar dan Menengah menerangkan mengenai pelaksanaan pembelajaran pada satuan pendidikan dan pendidikan menengah untuk 
mencapai kompetensi lulusan. Kurikulum 2013 merupakan kurikulum yang mulai diterapkan sejak tahun ajaran 2013/2014. Kurikulum 2013 adalah pengembangan kurikulum dari kurikulum sebelumnya yaitu kurikulum tingkat satuan pendidikan (KTSP). Meskipun begitu, penerapan kurikulum 2013 masih belum cukup efektif, sehingga diperbaiki lagi menjadi kurikulum 2013 revisi. Kurikulum 2013 Revisi merupakan penyempurnaan kurikulum yang berbasis karakter sekaligus kompetensi yang diberlakukan pada tahun ajaran 2017/2018. Dalam mengimplementasikan pembelajaran Kurikulum 2013 Revisi yang menuntut para pendidik mengembangkan pembelajaran dengan mengintegrasikan empat hal penting yaitu Penguatan Pendidikan Karakter (PPK), Literasi, Keterampilan abad 21 (4C) dan Higher Order Thinking Skill (HOTS) yang memerlukan kreativitas guru (Mulyasa,2018).

Pemberlakuan Kurikulum 2013 Revisi yang dilakukan bertahap merupakan usaha negara Indonesia untuk menyiapkan generasi emas yang berkualitas. Perubahan kurikulum merupakan hal yang sangat sulit untuk dilakukan. Konsep pendidikan abad 21 ini, mengubah pembelajaran yang semulanya tradisional menjadi pendidikan modern untuk menjamin peserta didik memiliki pengetahuan, keterampilan belajar dan berinovasi tinggi, serta keterampilan menggunakan teknologi untuk mencari informasi, dan bertahan dengan menggunakan keterampilan untuk life skills Higgins, 2014; Henriksen at al, 2016; Acedo dan Hughes, 2014 (dalam sipayung, 2018). Sekolah mampu membekali siswa berbagai kompetensi di atas sehingga dapat berkompetisi pada abad 21.

Implementasi pembelajaran berbasis $4 \mathrm{C}$ yang meliputi critical thinking and problem solving, creativity and innovation, communication, dan collaboration dalam proses pembelajaran. Setiap siswa memiliki cara belajar yang berbeda-beda, sehingga guru ditantang menciptakan cara untuk membatu siswa mampu belajar secara efektif. Dalam pelaksanaan pembelajaran siswa harus mampu mengasah keterampilan dan meningkatkan belajar untuk bisa mengatasi tantangan global, seperti keterampilan berpikir kritis, kemampuan berkomunikasi secara efektif, berinovasi dan memecahkan masalah melalui negosiasi dan kolaborasi. Namun demikian, dari sisi pedagogi belum disesuaikan untuk mengatasi tantangan-tantangan tersebut. Meskipun penerapan kurikulum 2013 sudah diberlakukan di seluruh sekolah, namun terdapat sekolah yang masih memiliki kendala dan terdapat sekolah yang sudah menerapkannya dengan baik.

Sebagai sekolah yang sudah menerapkan kurikulum 2013 yang berbasis 4C dalam proses pembelajarannya, SMA Negeri 2 Semarapura telah memikirkan kualitas peserta didik yang berkualitas di masyarakat. Sekolah ini juga memiliki program pembelajaran yang sudah direncanakan dan dilaksanakan dengan baik. Selain itu, perencanan dan pelaksanaan pembelajaran yang dilakukan guru telah dilakukan semaksimal mungkin sesuai dengan tuntutan kurikulum 2013 yang berlaku.

Berdasarkan hasil wawancara awal dengan guru bahasa Jepang di SMA Negeri 2 Semarapura, memperoleh informasi bahwa sekolah ini merupakan sekolah yang memiliki prestasi dalam bidang akademik maupun non akademik. Salah satu prestasi yang pernah diraih oleh siswa-siswi di sekolah ini yatu meraih peringkat pertama dalam lomba pidato bahasa Jepang, lomba origami dan lomba anime yang diselenggarakan oleh MGMP bahasa Jepang Provinsi Bali. Namun, selama pengalaman beliau mengajar masih mengalami kendala dalam menerapkan pembelajaran berbasis $4 \mathrm{C}$ (communication, collaboration, critical thinking, dan creativity).

Dalam menerapkan pembelajaran yang meliputi keterampilan 4C di perlukan langkahlangkah pembelajaran. Apabila langkah-langkah sudah direncanakan secara matang, maka pembelajaran akan berjalan dengan lancar dan dalam mengajar guru tidak akan mengalami kesulitan. Selain itu, dengan adanya langkah-langkah pembelajaran akan terlihat implementasi pembelajaran berbasis $4 \mathrm{C}$ yang digunakan oleh seorang guru. Jadi, langkahlangkah pembelajaran sangat penting untuk mengetahui implementasi pembelajaran berbasis $4 \mathrm{C}$ dalam proses pembelajaran bahasa Jepang.

Penelitian yang sebelumnya pernah dilakukan oleh Mirayanti (2018) dengan mengangkat tema penerapan pendekatan saintifik dalam pembelajaran bahasa Jepang di kelas $X$. Penelitian ini merupakan penelitian deskriptif kualitatif dengan subjek guru bahasa Jepang SMA Negeri 1 Amlapura. Hasil dalam penelitian menunjukan bahwa guru bahasa Jepang sudah menerapkan $5 \mathrm{M}$ sesuai dengan teori, namun belum berjalan dengan utuh karena pada kegiatan menanya siswa tidak ada yang bertanya kepada guru. Perbedaan penelitian 
ini dengan penelitian sebelumnya yaitu terletak pada aspek penerapan, subjek, dan objek yang diteliti. Aspek penerapan dalam penelitian ini yaitu menekankan pada aspek keterampilan 4C.

Subjek penelitian ini yaitu guru bahasa Jepang SMA Negeri 2 Semarapura dan objek penelitian ini implementasi pembelajaran berbasis 4C. Pada penelitian sebelumnya yang menjadi aspek penerapan yaitu penerapan pendekatan saintifik, subjek penelitian yaitu guru bahasa Jepang SMA Negeri 1 Amlapura, dan objek penelitian yaitu difokuskan pada penerapan pendekatan saintifik di kelas $X$.

Adapun rumusan masalah dari penelitian ini adalah sebagai berikut.

1. Bagaimana implementasi pembelajaran berbasis $4 \mathrm{C}$ oleh guru bahasa Jepang di SMA Negeri 2 Semarapura?

2. Apa saja kendala-kendala yang dihadapi dalam mengimplementasikan pembelajaran berbasis 4C di SMA Negeri 2 Semarapura?

Dalam penelitian ini menggunakan beberapa teori yang mendukung proses penelitian. Landasan teori yang digunakan adalah 1) kurikulum 2013 revisi, 2) pembelajaran abad 21 berbasis 4C (critical thinking and problem solving, creativity and innovation, communication, and collaboration).

Dalam penelitian ini membahas tentang implementasi pembelajaran berbasis $4 \mathrm{C}$ serta kendala yang dihadapi guru dalam pengimplementasikan pembelajaran berbasis $4 \mathrm{C}$ pada pembelajaran bahasa Jepang di SMA Negeri 2 Semarapura

\section{Metode}

\section{Jenis dan Pendekatan}

Penelitian ini menggunakan pendekatan deskriptif kualitatif. Penelitian deskriptif kualitatif merupakan metode penelitian yang menginterpretasikan objek yang sesuai dengan apa adanya tentang suatu variable gejala atau keadaan. Pada penelitian ini data yang diperoleh bukan dalam bentuk angka maupun bentuk bilangan melainkan dalam bentuk kata-kata.

Penelitian ini akan dilakukan di SMA Negeri 2 Semarapura yang berlokasikan di jalan Dewi Sartika, Semarapura Kaja, kecamatan Klungkung, kabupaten Klungkung. Lokasi ini dipilih karena pemiliki pontensi yang baik dalam bidang akademik. Fokus penelitian ini terletak pada implementasi pembelajaran berbasis $4 \mathrm{C}$ oleh guru bahasa Jepang.

\section{Sumber Data}

Subjek penelitian merupakan hal, benda, atau orang tempat variable melekat dan dipermasalahkan dalam penelitian. Dengan demikian, subjek dalam penelitian ini adalah guru yang mengajar bahasa Jepang di SMA Negeri 2 Semarapura. Pengalaman yang dimiliki dalam mengajar bahasa Jepang yaitu 4 tahun mengajar di SMA Negeri 2 Semarapura.

Alasan sekolah ini dipilih karena sekolah tersebut sudah mampu menerapkan pembelajaran berbasis $4 \mathrm{C}$ dengan baik. Hal itu terlihat dari hasil belajar siswa yang terus meningkat, mampu berkomunikasi menggunakan bahasa Jepang. Selain itu, memiliki fasilitas dan media pembelajaran yang cukup baik dan program sekolah yang mendorong siswa mengembangkan minat, bakat serta keterampilan yang dimiliki siswa hingga ditingkat nasional. Untuk itu, dengan hasil penelitian yang dapat dicapai pada penelitian diharapkan dapat menjadi refrensi terhadap pengembangan siswa dalam membekali keterampilan yang dimiliki.

Objek dalam penelitian ini adalah 1) implementasi pembelajran berbasis $4 \mathrm{C}$ oleh guru bahasa Jepang di SMA Negeri 2 Semarapura; 2) kendala-kendala yang terjadi dalam mengimplementasikan pembelajaran berbasis 4C di SMA Negeri 2 Semarapura.

\section{Metode Pengumpulan data}

Kualitas pengumpulan data merupakan faktor utama yang sangat memengaruhi kualitas hasil data penelitian selain kualitas instrument data. Oleh karena itu, dalam penelitian ini mengumpulkan data yang tepat peneliti menggunakan dua metode yaitu metode observasi dan metode wawancara.

Metode observasi merupakan teknik mengumpulkan data dengan cara mengamati 
kegiatan yang sedang berlangsung, mencatat dengan alat observasi tentang hal-hal yang akan diamati atau diteliti. Jadi, metode observasi yang dilakukan adalah observasi partisipasi pasif pada saat kegiatan belajar mengajar di kelas berdasarkan rumusan masalah dan tujuan penelitian, maka peneliti menggunakan metode observasi partisipasi pasif, karena peneliti hanya mengamati dan mencatat dalam lembar observasi selama proses pembelajaran di SMA Negeri 2 Semarapura tanpa ikut berpartisipasi dalam kegiatan belajar mengajar yang berlangsung. Metode observasi ini bertujuan untuk mencari data mengenai implementasi pembelajaran berbasis $4 \mathrm{C}$ oleh guru bahasa Jepang di kelas X IBB 1 SMA Negeri 2 Semarapura.

Dalam penelitian ini menggunakan metode wawancara. Dalam penelitian ini metode wawancara digunakan untuk melengkapi data yang diperoleh melaui observasi. Wawancara dilaksanakan pada hari Kamis 19 September 2019.

Metode wawancara diperlukan untuk menjawab rumusan masalah penelitian kendala yang dihadapi guru dalam mengimplementasikan pembelajaran berbasis $4 \mathrm{C}$. Jenis metode wawancara yang digunakan adalah wawancara semi terstruktur. Peneliti menggunakan metode wawancara semi terstruktur karena pewawancara telah menyiapkan sejumlah pertanyaan berkaitan dengan implementasi pembelajaran berbasis 4C yang dilakukan oleh guru bahasa Jepang di SMA Negeri 2 Semarapura, tetapi tidak menutup kemungkinan jika saat wawancara berlangsung terdapat hal yang penting diluar dari pertanyaa yang telah disiapkan dalam pedoman wawancara. Hal ini bertujuan agar penyajian data lebih rinci dan akurat mengenai implementasi pembelajaran berbasis $4 \mathrm{C}$.

\section{Teknik Analisis Data}

Metode analisis data dengan menggunakan metode deskriptif kualitatif dilakukan sesuai dengan keadaan yang sebenarnya. Metode yang digunakan sesuai dengan teori-teori yang relevan. Metode dan teknik analisis data yang digunakan bertujuan untuk mendapatkan gambaran tentang imlementasi pembelajaran berbasis 4C oleh guru bahasa Jepang di SMA Negeri 2 Semarpura. Teknik analisis data yang digunakan dalam penelitian ini dibagi menjadi lima langkah yaitu, (1) reduksi data, (2) deskripsi data, dan (3) penarikan kesimpulan.

\section{1) Reduksi Data}

Reduksi data merupakan proses pemilihan, penyederhanaan dan peringkasan data mentah yang dilakukan dengan penyederhanaan data dari hasil observasi dan juga hasil wawancara. Dalam penelitian ini, reduksi data dilakukan dengan penyederhanaan data yang diperoleh dari hasil observasi kegiatan pembelajaran bahasa Jepang di SMA Negeri 2 Semarapura dan wawancara dengan guru bahasa Jepang.

\section{2) Deskripsi Data}

Dalam tahap deskripsi data, seluruh data yang diperoleh melalui hasil observasi dan hasil wawancara dideskripsikan sesuai dengan fakta yang ditemukan di lapangan. Pendeskripsian ini dilakukan berdasarkan sub masalah yang telah dipaparkan dalam rumusan masalah.

\section{3) Penarikan Kesimpulan/ Verifikasi}

Simpulan dirumuskan berdasarkan data yang diperoleh dan menyiapkan kembali menggunakan deskriptif kualitatif dengan kata-kata. Penarikan kesimpulan ini disesuaikan dengan data yang valid yang ditemukan di lapangan. Setelah proses ini barulah peneliti dapat menarik kesimpulan yang merupakan jawaban atas permasalahan dari penelitian ini. Data yang diperoleh di lapangan diperiksa kembali, kemudian dilakukan bimbingan dengan dosen untuk hasil yang maksimal.

\section{Hasil dan Pembahasan}

Implementasi pembelajaran berbasis $4 \mathrm{C}$ yang dilaksanakan guru bahasa Jepang di SMA Negeri 2 Semarapura telah dilaksanakan dengan baik. SMA Negeri 2 Semarapura merupakan sekolah yang sudah menerapkan pembelajaran berbasis 4C sejak tahun 2016 dan sudah berjalan 4 tahun. Langkah-langkah pembelajaran dengan menggunakan pembelajaran berbasis $4 \mathrm{C}$ meliputi, kemampuan berfikir kritis dan memecahkan masalah 
(critical thinking and problem solving skill), kemampuan menciptakan dan membaharui (creativity and innovation skill), kemampuan berkomunikasi (communication skill), dan kemampuan bekerjasama (collaboration skill).

\section{Critical Thinking and Problem Solving Skill}

Dalam menerapkan kegiatan critical thinking and problem solving skill pada pembelajaran bahasa Jepang, guru diharuskan memiliki persiapan untuk memberikan pengetahuan baru kepada peserta didik. Critical thinking and problem solving skill diterapkan pada tahan awal sebelum memasuki materi baru. Seperti yang diungkapkan Trilling dan Fadel (2009) menyatakan bahwa kecakapan berpikir kritis dan pemecahan masalah merupakan proses mental untuk menganalisis informasi yang diperoleh.

Pada saat proses pembelajaran berlangsung, guru mengarahkan siswa untuk membuka buku pelajaran. Guru memberikan intruksi dengan menggunakan bahasa Jepang, hal itu dilakukan agar siswa terbiasa menggunakan bahasa Jepang. Berdasarkan observasi kedua dan keempat, kegiatan critical thinking and problem solving skill terlihat pada siswa melakukan aktifitas mengidentifikasi 2 gambar dari pandangan budaya yang berbeda yaitu budaya Jepang dan budaya Indonesia. Siswa memberikan berbagai pendapat mengenai gambar yang terdapat pada buku. Pada masing-masing gambar tersebut, terlihat siswa sedang memberikan salam kepada guru dalam pandangan kebudayan Jepang dan kebudayaan Indonesia. Ketika pembelajaran berlangsung, siswa belum menunjukan critical thinking and problem solving skill ini secara maksimal. Oleh karena itu, guru mengembangkannya dengan cara memberikan pertanyaan kepada siswa untuk mendorong dan meningkatkan kemampuan critical thinking and problem solving skill siswa. Kemudian guru meminta siswa untuk mengemukakan pendapat mengenai 2 gambar tersebut. Guru memberikan pertanyaan kepada siswa "apakah kalian di rumah setiap bangun pagi memberikan salam kepada keluarga di rumah?". Selanjutnya, guru mengarahkan siswa untuk menyusun dan mengungkapkan, menganalisa dan menyelesaikan suatu masalah dengan mencari perbedaan dan persamaan dari sudut pandang budaya Jepang dan budaya Indonesia.

Berdasarkan hasil observasi pertama dan ketiga, pada saat proses pembelajaran guru melanjutkan sisa materi yang sudah dijelaskan pada pertemuan sebelumnya. Guru menerapkannya dengan cara siswa melakukan identifikasi gambar dengan berisikan percakapan yang rumpang dan mencari tahu kosakata yang akan dipelajari melalui audio. Audio diputar sebanyak 3 kali. Putaran pertama siswa mendengarkan dengan seksama, putaran kedua siswa mencari jawaban terkait percakapan yang rumpang, putaran ketiga siswa mengecek kembali jawaban yang sudah ditemukan. Siswa terlihat sangat antusias saat proses pembelajaran berlangsung. Suasana kelas menjadi sangat hening, karena semua siswa fokus pada bunyi audio yang akan diputar. Seluruh siswa mencari jawaban terkait percakapan yang rumpang tersebut. Setelah seluruh siswa melengkapi bagian yang rumpang dalam percakapan tersebut, guru menjelaskan secara singkat terkait kosakata yang terdapat pada percapakan. Guru juga memberikan penekanan pada poin kosakata pada percakapan yang menjadi dasar pemahanman untuk diingat siswa.

Kegiatan critikal thinking and problem solving skill ini, belum sepenuhnya efektif karena siswa masih diberikan pertanyaan oleh guru. Guru lebih aktif memberikan pertanyaan saat kegiatan pembelajaran agar peserta didik memiliki kemampuan bernalar yang aktif. Hal tersebut berhasil menarik perhatian siswa untuk mengembangkan kemampuan critikal thinking and problem solving. Berdasarkan dari hasil observasi yang telah dipaparkan menunjukan bahwa siswa mampu menyelasikan permasalahan. Hal tersebut mendukung teori yang diungkapkan Ditjen (2017) kecapakan dalam crtical thinking and problem solving skill yaitu memahami interkoneksi antar satu konsep dengan konsep yang lain dalam mata pelajaran, menggunakan kemampuan yang dimiliki siswa untuk berusaha menyeselaikan masalah, dan menyusun dan mengungkapkan, menganalisa, dan menyelesaiakan masalah.

\section{Creativity and Innovation Skill}

Dalam penerapan kegiatan creativity and innovation skill terdapat pada akhir bab yang sudah dipelajarai peserta didik. Kegiatan creativity and innovation skill terlihat ketika siswa diberikan tugas rumah oleh guru. Sesuai dengan pendapat Munandar (2009) menyatakan 
creativity (kreativitas) yaitu kemampuan untuk menghasilkan sesuatu yang baru. Kreativitas peserta didik perlu diasah setiap hari agar menghasilkan terobosan atau inovasi baru bagi dunia pendidikan.

Pada kegiatan creativity and innovation skill ini, guru mengembangkannya sebagai tugas masing-masing siswa, karena waktu pembelajaran yang tersedia tidak banyak. Berdasarkan hasil observasi kedua, guru menugaskan siswa membuat projek berupa video perkenalan diri dengan siswa kelas lain. Siswa membuat projek yaitu berupa video perkenalan diri (jikoshoukai) terhadap teman dari kelas lain yang juga mendapatkan pelajaran bahasa Jepang. Guru mengarahkan siswa membuat projek video perkenalan diri tersebut menggunakan bahasa Jepang. Siswa bebas mengungkapkan hal apapun dalam memperkenalan diri namun tetap menggunakan bahasa Jepang. Setelah semua siswa mengumpulkan tugas tersebut, guru memeriksa tugas siswa. Pada saat siswa menggungkapkan kosakata dalam memperkenalkan diri, masih banyak siswa yang masih tergolong belum fasih menggunakan bahasa Jepang. Guru menuntun siswa dengan membantu mengungkapkan kosakata dalam memperkenalkan diri dengan benar dan memberi penekanan terhadap ungkapan penting.

Berdasarkan hasil observasi ketiga, kegiatan creativity and innovation ini berlangsung pada saat proses pembelajaran. Siswa diarahkan untuk membuat kartu nama, siswa membuat tersebut dengan menuliskan nama panggilan menggunakan huruf katakana sesuai dengan jumlah siswa yang ada dikelas dan menggunakannya untuk berkenalan dengan teman yang lain. Siswa terlihat antusias terhadap pembuatan kartu nama tersebut, karena untuk yang pertama kalinya siswa diajarkan menulis nama panggilan menggunakan huruf katakana. Pada saat pembelajaran, masih terlihat beberapa siswa yang mengungkapan kosakata belum fasih melainkan guru menunjukan ekspresi santai tetapi tegas. Hal ini dilakukan agar siswa tidak hanya menyimpan yang salah tetapi guru membantu siswa mengingat pelafalan yang benar.

Terkait hasil observasi keempat kegiatan creativity and innovation skill ini, guru memberikan siswa tugas rumah berupa pembuatan kartu ucapan hari ulang tahun. Pada pembuatan kartu ucapan hari ulang tahun, siswa membuat dengan menggunakan kertas origami ukuran 14x14. Siswa diminta untuk menuliskan ucapan dan harapan untuk salah satu teman sekelas. Kartu ucapan hari ulang tahun tersebut dibuat sesuai dengan kreatifitas masing-masing siswa dan menggunakan 4 bahasa yaitu bahasa Jepang, bahasa Indonesia, bahasa Inggris, dan bahasa Bali.

Pada saat kegiatan creativity and innovation skill, dalam proses pembelajaran guru harus menciptakan kondisi yang berkreasi dan berinovasi. Berdasarkan hasil observasi yang telah dipaparkan menunjukan bahwa siswa dapat mengembangkan kreativitas yang dimilikinya untuk menghasilkan berbagai trobosan yang inovatif dari hasil tugas yang dikumulkan siswa. Hal tersebut mendukung teori yang diungkapkan Ditjen (2017) kecapakan dalam creativity and innovation yaitu memiliki kemampuan dalam mengembangkan, melaksanakan, dan menyampaikan gagasan-gagasan baru secara lisan atau tulisan dan mampu mengemukankan ide-ide kreatif secara konseptual dan praktikal.

\section{Communication Skill}

Dalam penerapan kegiatan communication skill, sudah terlihat dari awal kegiatan pembelajaran sampai akhir kegiatan pembelajaran. Saat proses pembelajaran berlangsung, guru selalu memberikan instruksi siswa menggunakan bahasa Jepang. Guru mengajarkan seluruh siswa untuk terbiasa menggunakan bahasa Jepang baik di dalam kelas ataupun di luar kelas. Kegiatan communication skill ini terlihat juga pada saat siswa mampu menggunakan bahasa Jepang secara lisan. Berdasarkan hasil observasi pertama, kegiatan communication skill terlihat pada saat materi yang disampaikan mengenai "bagaimana cara meminta izin pergi ke toilet dengan guru", siswa menerapkannya dengan baik. Pada saat proses pembelajaran terdapat siswa yang ingin pergi ke toilet, kemudian guru meminta siswa untuk menyampaikannya menggunakan bahasa Jepang seperti apa yang telah dipelajari. Sudah terlihat jelas siswa mampu menggunakan bahasa Jepang lisan yang sesuai konten dan konteks pembicaraan dengan guru. Terkait hasil observasi kedua dan ketiga, kegiatan communication skill terlihat ketika siswa melakukan aktifitas berlatih percakapan terkait materi yang sudah dijelaskan oleh guru. 
Berdasarkan hasil observasi keempat, kegiatan communication skill ini terlihat ketika siswa melakukan aktifitas mewawancari teman sekelasnya menggunakan bahasa Jepang terkait "kapan hari ulang tahunmu?". Sebelum siswa melakukan wawancara tersebut, guru menjelaskan materi terlebih dahulu. Pada saat guru menjelaskan materi mengenai "hari ulang tahun", siswa memperhatikan penjelasan dari guru dengan seksama. Setelah selesai menjelaskan materi, guru mengarahkan siswa untuk mewawancari teman sekelasnya terkait kapan hari ulang tahunnya. Siswa mengajukan pertanyaan menggunakan bahasa Jepang seperti "otanjoubi wa itsu desuka", kemudian siswa menjawabnya menggunakan bahasa Jepang. Meskipun pelafalan siswa dalam berbiacara masih belum fasih, guru selalu memberikan respon yang positif terhadap siswa dan memberikan contoh dengan pelafalan yang benar. Hal tersebut mendukung teori yang diungkapkan oleh Ditjen (2017) kecakapan dalam communication skill yaitu memahami, mengelola dan menciptakan komunikasi yang efektif dalam berbagai bentuk dan menggunakan bahasa lisan yang sesuai konten dan konteks pembicaraan dengan lawan bicara.

\section{Collaboration Skill}

Dalam penerapan kegiatan collaboration skill, guru mampu mengatur yang singkat saat proses pembelajaran berlangsung. Selain itu, guru harus mampu mengelola kelas agar suasana kelas tetap kondusif. Kegiatan collaboration skill terlihat pada akhir proses pembelajaran. Berdasarkan hasil observasi pertama, yang terlihat saat aktifitas guru membagi siswa menjadi 5-6 kelompok untuk membuat puzzle hiragana. Guru meminta siswa untuk membuat puzzle hiragana dengan membagikan 2 kertas A4. Satu kertas A4 berisikan gambar tokoh anime Jepang dan satu kertas A4 kosong. Siswa diminta untuk mengikuti intruksi sesuai di buku pelajaran. Selanjutnya siswa berdiksi dengan teman sekelompoknya, kemudian membagi tugas dan mengerjakan tugas masing-masing. Setelah selesai siswa diminta untuk mempresentasikan di depan kelas dan kelompok yang lain menanggapi hasil dari kelompok presentasi.

Terkait hasil observasi keempat, pada saat proses pembelajaran guru mengintruksikan siswa untuk membagi kelompok sesuai dengan bulan kelahiran masing-masing siswa dan siswa diminta untuk mewawancarai teman sekelompoknya terkait hari ulang tahun. Seluruh siswa merespon dengan cepat dan suasana kelas menjadi tidak kondusif lagi. Meskipun suasana kelas tidak kondusif, guru tetap menuntun siswa dengan sabar agar suasana kelas kembali kondusif. Pada saat kegiatan siswa mewawancarai teman sekelompoknya terlihat jelas kemampuan collaboration ini mengalami peningkatan. Hal ini terlihat, siswa memiliki bentuk kerjasama yang tinggi dalam dalam mencapai satu tujuan bersama. Berdasarkan dari hasil observasi yang telah dipaparkan kegiatan collaboration dalam proses pembelajaran merupakan bentuk kerjasama dengan teman yang lain. Hal tersebut mendukung teori yang diungkapkan oleh Ditjen (2017) yaitu memiliki kemampuan dalam kerjasama kelompok, beradaptasi dalam berbagai peran dan tanggung jawab, bekerja secara produktif dengan yang lain, dan mampu berkompromi dengan anggota lain dalam kelompok demi mencapai tujuan yang telah ditetapkan.

Pembelajaran berbasis $4 \mathrm{C}$ masih tergolong baru terutama pada pembelajaran bahasa Jepang. Dalam penerapannya guru masih menemukan kendala dalam mengimplementasikannya. Namun, dari kendala tersebut guru mampu mengatasinya dengan baik. Sesuai pada pembahasa yang sudah dipaparkan, bahwa implementasi pembelajaran berbasis 4C yaitu critical thinking and problem solving (kecakapan dalam berfikir kritis dan pemecahan masalah), creativity and innovation (kecakapan dalam kreatif dan inovasi), collaboration (kecakapan dalam kolaborasi), dan communication (kecakapan dalam komunikasi). Penerepan pembelajaran berbasis 4C sudah berjalan dengan baik dan sesuai dengan langkah-langkah pembelajaran 4C. Maka dari itu, langkah-langkah pembelajaran harus direncanakan secara matang, sehingga pembelajaran akan berjalan dengan lancar.

Adapun kendala-kendala yang dihadapi guru dan cara mengatasi kendala tersebut yaitu, Kendala yang dihadapi guru dalam menerapkan pembelajaran berbasis $4 \mathrm{C}$ terdapat pada kegiatan critical thinking and problem solving skill. Pada kegiatan ini, terdapat kendala yang dialami guru yaitu sebagian kecil siswa kurang aktif dalam kegiatan pembelajaran. Hal tersebut, terlihat dari sikap siswa yang kurang bertanya terkait materi yang sudah dijelaskan 
dan cendrung menunggu pertanyaan dari guru. Solusi yang dilakukan guru adalah guru tidak hanya menyampaikan materi melainkan juga lebih berperan aktif untuk merangsang keingintahuan siswa.

\section{Simpulan dan Saran}

\section{Simpulan}

Implementasi pembelajaran berbasis 4C oleh guru bahasa Jepang di SMA Negeri 2 Semarapura sudah dilaksanakan dengan baik dan berjalan dengan optimal. Hal tersebut terlihat dari hasil observasi yang telah dilakukan. Respon siswa terhadap kegiatan pembelajaran berbasis $4 \mathrm{C}$ meningkat dan guru terlihat aktif memberikan stimulus terhadap siswa.

Kendala yang dihadapi guru dalam menerapkan pembelajaran berbasis $4 \mathrm{C}$ terdapat pada kegiatan critical thinking and problem solving skill. Pada kegiatan ini, terdapat kendala yang dialami guru yaitu sebagian kecil siswa kurang aktif dalam kegiatan pembelajaran. Hal tersebut, terlihat dari sikap siswa yang kurang bertanya terkait materi yang sudah dijelaskan dan cendrung menunggu pertanyaan dari guru. Solusi yang dilakukan guru adalah guru tidak hanya menyampaikan materi melainkan juga lebih berperan aktif untuk merangsang keingintahuan siswa. Hal ini terlihat ketika guru mengarahkan siswa untuk mengindentifikasi gambar/ujaran yang terdapat pada buku, siswa masih terlihat kebingungan memahami gambar/ujaran tersebut. Tindakan guru yang dilakukan memberikan perjelasan yang lebih mudah dipahami oleh siswa dan memberikan contoh sesuai dengan kehidupan sehari-hari.

\section{Saran}

(1) Guru diharapkan meningkatkan dan mengembangkan pembelajaran dengan inovasi baru yang membuat siswa semakin aktif didalam proses pembelajaran berlangsung.

(2) Untuk peneliti lainnya, diharapkan dapat melakukan penelitian sejenis tentang implementasi terkait pembelajaran HOTS (higher order thinking skill).

\section{Daftar Pustaka}

Direktorat Pembinaan Sma Direktorat Jenderal Pendidikan Dasar Dan Menengah Kementerian Pendidikan Dan Kebudayaan. 2017. Implementasi Pengembangan Kecakapan Abad 21 Dalam Perencanaan Pelaksanaan Pembelajaran (Rpp).

Mulyasa, H.E. 2018. Implementasi Kurikulum 2013 Revisi. Jakarta Timur: PT. Bumi Aksara.

Munandar, Utami. 2009. Pengembangan Kreativitas Anak Berbakat. Jakarta: Rineka Cipta.

Sipayung, Hari Diana. 2018. "Pengaruh Model Pembelajaran Collaboratif And Inquiry Terhadap Keterampilan 4C Siswa Disma” Jurnal Pascasarjana Pendidikan Fisika. Universitas Negeri Medan.

Undang-Undang Nomor 20 tahun 2003 tentang Sistem Pendidikan Nasional. 